\title{
My Solidarity Memories from Gdańsk
}

\section{ANDRZEJ SNARSKI}

Like most members of my generation, I grew up with vivid memories of the brutal suppression of workers' protests in Gdańsk in December 1970. At that time, the communist authorities ordered the army and the police to open fire on the protesters. About 45 people were killed - most of them secretly buried by the security forces - and about 1200 were injured. It was an entirely avoidable national tragedy and the source of national trauma, leading to the formation of organised opposition and the creation of an underground free trade union movement in Poland.

I witnessed this tragedy - the most important formative experience for my generation - while serving in the Polish Navy. During a purge of Polish universities in May 1969, I was conscripted to the navy for two years from the post of medical registrar, while finishing my $\mathrm{PhD}$ in the Nephrology Department, Medical School of Gdańsk, under a prominent medical scholar, Professor Jakub Penson, who was himself suspended from the position of Vice-Chancellor. Nevertheless, when I was conscripted, Penson found for me through his friends in the army a position in a small navy garrison on the Westerplatte Peninsula in Gdańsk and helped me to finish my doctorate while I was serving in the navy.

On Westerplatte, I was in charge of a clinic and a small hospital. Some of my patients were university students conscripted for three years' military service as punishment for activity in democratic opposition. I also had under my care soldier-conscripts from Catholic seminaries who were forced to take three years of military service in the Navy Artillery. They were subject to intense 're-education', which was shorthand for brainwashing, involving lectures and parties with local prostitutes, all aimed at 'ideological conversion' of the young clerics.

On 15 December 1970, when the clashes between the police and the protesters started in Gdańsk, I was on duty at the Nowy Port Garrison, charged with attending the injured policemen. Fighting in the city was very intense, and there were more than 400 injured policemen brought in for emergency treatment. Almost all of them were under the influence of alcohol and drugs given to 
them by officers before their deployment. While putting them in plaster (to immobilise them temporarily), I could not stop thinking about the carnage they might have inflicted on the protesters.

Two days later, army helicopters fired at the workers arriving by trains at Gdynia Shipyard and more people were killed. The navy was not involved in the clashes, and it was a great relief when, after a few more days and a change in communist leadership, there was a political 'thaw'. But there was also a growing concern about the 're-educated' soldiers. When a few warships entered Westerplatte and I had an opportunity to chat with navy crews, I discovered that they were thoroughly brainwashed. Political officers convinced the soldiers that the protests were provoked by German 'revanchists', and that the police and the army defended the 'Polish Gdańsk'.

Ten years later, I was a university lecturer and director of the Nuclear Medicine Department at the Medical School of Gdańsk, busy completing my habilitation (advanced research degree). I had a new boss, a member of the Central Committee of the Communist Party, who was reorganising the Medical School on the Soviet model. In spite of political pressures, we had at the university a small but active group of oppositional critics, mostly young doctors and students, who called themselves 'Young Poland'. They were unofficially allied with underground free trade unions that formed in the late 1970s.

When protest started to spread again in spring 1980, this was a sign of forthcoming upheavals. Indeed, the spring wave of strikes was followed in July-August by a new wave that spread to the Gdańsk Shipyard. This time there were no street marches like those that had triggered violence 10 years earlier-only strikes in the factories. The strikers demanded not only better working conditions, but also the commemoration of colleagues killed in 1970 and, importantly, the legalisation of the free trade union Solidarność.

These were days of anxiety and excitement. Hundreds of strikers locked themselves in the shipyard. Thousands of their supporters gathered daily in front of the shipyard gates, bringing food and information. In spite of the information blockade, millions of sympathisers around the country turned their eyes on the coast. The police and the security forces desperately tried to isolate the strikers by cutting telephone lines and stopping the mail. Interestingly, they were unable to block the telex network between large industrial plants and universities. Thus, while the official news services were blocked and censored, the strikers could use telexes - soon supplemented by underground leaflets - to communicate with the outside world.

Who were the strikers and first members of Solidarity? My observation was that these were mainly highly skilled and educated young people, typically 
tradesmen and young engineers produced en masse by Polish polytechnic universities and trade schools. Most were 'underemployed' as skilled workers in industrial plants, such as the Gdańsk Shipyard, mainly because such plants offered better wages, as well as good chances of promotion. They were young, ambitious and frustrated by poor organisation, inefficiency and regular shortages of goods. Like all of us, they also shared memories of the massacre in 1970 and harboured deep anger at police brutality.

From day one, the people of Gdańsk supported the striking workers by gathering around the shipyard walls, praying with the workers, and bringing food and money collected by sympathisers. Soon, the ranks of the supporters started to grow, swelled by the families, friends, local sympathisers, and a growing number of intellectuals coming from Warsaw to offer support and advice. The shipyard gates turned into a place of heated discussions - a free public agora in the midst of the authoritarian order.

After a few weeks, Solidarity Strike Committees unofficially ruled the entire city of Gdańsk, while police disappeared from the streets and moved into the peripheries. Around the city, we could also see massive concentrations of Polish security forces, while in the Bay of Gdańsk, several Soviet warships were waiting ready to offer 'fraternal help'.

For Solidarity, the most immediate task was to prevent street riots that could be used as an excuse for violent suppression of protests. They formed citizen patrols that maintained order and prevented provocations. It was an incredible time in Gdańsk's history. The streets were in perfect order: people were cheerful and polite, crime virtually disappeared, and there were no drunks because alcohol was banned by the Strike Committee. The security forces tried to break this order by smuggling into the supermarkets lemonade mixed with vodka, but the transport was stopped and the drink discharged into the sewerage system.

Another public response was massive attendance of church services. People were scared, and they sought hope and encouragement in their faith and the Catholic Church. They understood how fragile and dangerous the political situation was, and were uniting in prayers, appeals to the church authorities for mediation, and calls for support to the newly elevated Polish Pope, John Paul II. It was a deeply moving experience: hundreds of people gathering daily in open-air masses in front of the shipyard gate, under pictures of the Pope and the Black Madonna.

And it looked like these prayers were answered. At the end of August 1980, the strikers announced that the negotiations were successful and that the authorities accepted the famous ' 21 demands' formulated by the strikers. This 
included the formation of the free and self-governing trade union 'Solidarity', and commemoration of the 1970 massacre. Perhaps it was not a real miracle, but many people did believe that it was.

The victory of the Gdańsk Great Strike opened the way for the registration of free trade unions in all factories and institutions, as well as the relaxation of censorship and loosening of political control. I had the honour of chairing the first 'free and democratic' general meeting of Solidarity at the Gdańsk Medical School. The atmosphere at the meeting was amazing: highly charged yet dignified. It was the first normal democratic meeting and election in all our lives, and everyone felt that there was suddenly a new Poland, a new democratic society emerging in front of us.

Solidarity was open to everyone, regardless of previous political affiliations. It was also operating openly, partly out of enthusiastic commitment to democratic transparency and partly to avoid accusations of anti-communist subversion. Inevitably, secret agents infiltrated the union, making provocative statements and causing conflicts. There was also a massive anti-Solidarity propaganda campaign accusing the free union of fomenting anarchy and undermining the 'socialist order'. There were also the first thinly veiled threats of Soviet 'fraternal help'. In the heady days of September and October 1980, though, few people were concerned about these threats and about the official propaganda.

Public attention turned elsewhere. On 16 December 1980, 10 years after the massacre of workers in 1970, the commemorative monument was unveiled: three massive crosses erected in front of the Gdańsk Shipyard gates. I was a doctor on duty at the ceremony. It was attended by hundreds of thousands of people. The atmosphere was very tense, as news circulated of a possible Soviet invasion that night. That proved to be a lie, but many people were genuinely scared. The tension was palpable and emotions were high. When the Polish Army battalion fired the honour salvoes and the names of the killed workers-now declared national heroes - were called, there was no single dry eye in the crowd. People experienced the great feeling of catharsis, a sense of justice finally delivered, though only in a symbolic way. That was one of the most memorable experiences of Solidarity's 15 months of freedom.

In September 1981, I took part in negotiations between the Solidarity Union of all Polish medical schools and the Health Ministry in Warsaw. After difficult discussions, the Solidarity draft rules for the elections of officials governing medical schools were accepted and, in September, we started election meetings. This was the only way to get rid of the communist nomenklatura (nomenclature) and elect honest people to run the medical universities. I was chairman of an election meeting at the Gdańsk Medical School that was attended by academics, doctors, nurses, medical students and administrative staff. Students from 
the Independent Students' Association were very helpful with questioning Communist Party activists and corrupt clinicians. After a few embarrassing questions, discredited candidates gave up and left the hall. Consequently, we managed to elect an excellent team consisting mostly of academics from non-clinical departments. They proved not only excellent managers, but also good colleagues and devoted friends, protecting staff members from political repression. They were all removed from their positions in early 1982.

In October 1981, my wife, Joanna, got her first overseas scholarship and left for Paris. In November, I started getting ominous warnings from the nomenklatura people that the days of Solidarity were numbered. The 'sources' were confident that they would be back in power soon. On 6 December, I submitted my Doctor Habilitatus paper and started thinking about joining my wife in France for skiing holidays. Seven days later, on Sunday 13 December, martial law was proclaimed. It was a shock and a terrible humiliation. Although everybody was tired of chaos and daily conflicts - in most cases, provoked by the authorities few expected such a brutal response. Suddenly, we woke up to a South American golpede estado and a party-military dictatorship.

I remember my first encounter with military rulers. My elderly parents were confronted by a militia patrol marching straight on them with their batons ready for use. My parents had to give way to them and step into deep snow to avoid being pushed. Their comment was: 'It is like Gestapo during the war!'

Many friends were arrested. One of the first was Professor Joanna MuszkowskaPenson, wife of the late Jakub Panson, and ex-prisoner of Ravensbruck. As I subsequently learned from Wałęsa's memoirs, she was a secret personal physician for the imprisoned Solidarity leader.

The new military authorities demanded discipline, obedience and collaboration. Refusal to cooperate inevitably attracted sanctions: firing, blacklisting, fines, and daily bureaucratic harassment. Life became bleak, full of uncertainties, daily humiliations and constant irritations.

In March 1982, I sent a message to my wife that I had had enough, and was planning to defect. I applied for a passport to attend a medical conference, which I miraculously received with minimal delays, and, in May 1982, I was finally reunited with my wife in Paris. It was a bittersweet reunion: we were together, free, but with the way back closed - as we then thought, for ever. In June 1983, we arrived in Melbourne, joining thousands of Polish 'Solidarity refugees'. 